\title{
A Perilous History: A Historiographical Essay on the French Resistance
}

\author{
Laurent Douzou* \\ 73, rue Brillat-Savarin 75013 Paris, France \\ *laurent.douzou@gmail.com
}

The history of the French resistance began to be written as early as April 1944, when JeanJacques and Roland published in Algiers a brief, 144-page narrative entitled La Résistance française. ${ }^{1}$ Jean-Jacques was the nom de guerre of Jean-Jacques Soudeille, one of the founders of Franc-Tireur ${ }^{2}$ and a member of the Provisional Consultative Assembly (Assemblée Consultative Provisoire). ${ }^{3}$ 'Roland' was a former chief of armed groups in southern France, whom I have not been able to identify according to his surname. The following year the prominent resister and history teacher Lucie Aubrac penned a short synthesis in a collection proudly entitled "'Mises au point" (Clarification): The Resistance. Birth and Organization'. ${ }^{4}$ Here she painted a general picture, which despite a few inevitable inaccuracies came across as both authentic and inspiring. At the end of January 1946 two editions of Notes documentaires et études were published under the aegis of the Ministry of Information as A First Step Towards a History of the French Resistance (Esquisse d'une histoire de la Résistance française). ${ }^{5}$ This study - highly synthetic and realised without access to any written archives - was astonishingly precise for the time.

Many publications on the resistance were to follow, totalling almost 4,500 between 1946 and 2001. Surprisingly - considering this vast number - an overview of the full meaning of the term remains to be written. Beginning in 1950 with Henri Michel's Histoire de la Résistance in the well-known What do I know? (Que sais-je?) collection, ${ }^{6}$ there have been several rigorous and impressive overviews. These include Julian Jackson's France: The Dark Years, which covers the various aspects of the entire period $;^{7}$ Olivier Wieviorka's Histoire de la Résistance, $1940-1945 ;^{8}$ and Robert Gildea's Fighters in the Shadows. ${ }^{9}$ Yet none of these encompasses the whole picture. They have dealt mainly with the organised resistance (movements, networks, maquis), and the

\footnotetext{
Jean-Jacques and Roland, La Résistance française (Alger: Office français d'édition, 1944), (published on 30 Apr. 1944).

2 Alongside Combat and Libération, this was one of the three main movements of non-communist resistance in the unoccupied zone of France.

3 Created in Algiers, this assembly - which met for the first time on 3 November 1943 - brought together members of the internal resistance with members of trade unions and political parties.

4 Lucie Aubrac, La Résistance (naissance et organisation) (Paris: Robert Lang, 1945).

5 'Esquisse d'une histoire de la Résistance française', Notes documentaires et études (Paris: Ministère de l'Information, Direction de la documentation, 30-31 Jan. 1946) 225-6. This was anonymous but, according to Jean-Pierre Azéma and François Bédarida ('L'historisation de la Résistance', Esprit, Jan. 1994, 19-35), the author was Odette Merlat-Guitard, number 2 of the Commission d'Histoire de l'Occupation et de la Libération de la France.

6 Henri Michel, Histoire de la résistance, 1940-1944 (Paris: Presses Universitaires de France, 1950). There were ten subsequent editions, with the last one appearing in 1987.

7 Julian Jackson, France: The Dark Years, 1940-1944 (Oxford: Oxford University Press, 2001).

${ }^{8}$ Olivier Wieviorka, Histoire de la Résistance: 1940-1945 (Paris: Perrin, 2013).

9 Robert Gildea, Fighters in the Shadows: A New History of the French Resistance (Cambridge, Massachusetts: The Belknap Press of Harvard University Press, 2015). Translated into French as Comment sont-ils devenus résistants? (Paris: Les Arènes, 2017).
} 
challenge remains taking into account the ways in which the resistance was also a subtle framework more broadly rooted in society.

To reach this goal much remains to be done. Unlike Vichy France or the Vichy government, both of which have now been studied and documented in almost every respect, the French resistance is only partly known. Although many academics have shown an interest in it, the French resistance has turned out to be far less attractive an object of study than Vichy France, and equally less rewarding: the dark side is more appealing and certainly easier to explore as it is connected to the state apparatus. ${ }^{10}$ This is true both in France and abroad. ${ }^{11}$

\section{The Specificities of Resistance Historiography: Realities and Representations}

From 1944 until the beginning of the 1980s the idea prevailed that as a clandestine activity the resistance necessarily possessed few archives. Yet this was only partly the case, and the assumption persisted mainly because many archives were closed. There was also a widespread conviction that only a minority had been involved in clandestine activity: the general public knew, deep down, that the resistance had always been the preserve of a minority, a kind of elite. ${ }^{12}$ Everybody agreed that oral testimonies were therefore crucial. Indeed, two official committees were created in October 1944 and June 1945 in order to preserve the knowledge needed to write the future history of the resistance, ${ }^{13}$ subsequently merging in 1951 to become the Committee on the History of the Second World War (Comité d'histoire de la deuxième guerre mondiale; $\mathrm{CH} 2 \mathrm{GM}$ ). Under the supervision of Édouard Perroy, professor of medieval history at the University of Lille and former resister, these two committees collected more than 2,000 testimonies from resisters, mostly between 1945 and 1947. As late as the 1980s and 1990s nobody studied the French resistance without using these sources and carrying out their own oral history. In the 1980s, for example, those of us studying a resistance movement, such as Alya Aglan, Olivier Wieviorka and myself, collected as many testimonies as we could. ${ }^{14}$ Yet this period now belongs to the past. We have reached a turning point: the very last resisters are fast disappearing, with fewer than five Compagnons de la libération still alive in August 2018 (out of approximately 700 in 1945). ${ }^{15}$

Another very particular influence on resistance historiography has been the axiom that only those who participated in the movement are suitably qualified to write about it: unlike other heroic moments of twentieth-century history, the resistance was a clandestine and elusive adventure intimately known only by its members. For at least thirty years the result of this axiom

10 Robert Paxton, Vichy France: Old Guard and New Order, 1940-1944 (Barrie \& Jenkins, 1973), translated into French as La France de Vichy, 1940-44 (Paris: Le Seuil, 1973). Paxton's book had a tumultuous reception in France but, according to Henry Rousso, it has now become a 'Site of Memory'. See Sarah Fishman, Laura Lee Downs, Ioannis Sinanoglou, Leonard V. Smithand Robert Zaretsky, eds., France at War. Vichy and the Historians (New York: Berg, 2000).

11 For example, there were no articles about the French resistance in The American Historical Review between 1945 and 2001; French Historical Studies published its first article on the subject in 1985 and four other articles until 2004.

12 Henry Rousso, The Vichy Syndrome (Cambridge, MS: Harvard University Press, 1991), foreword by Stanley Hoffmann, viii: 'the general public, which deep down knew that the myth was a cavalier interpretation of reality, pretended that it was indeed the truth'.

13 The Commission d'histoire de l'Occupation et de la Libération de la France in October 1944 and Le Comité d'Histoire de la Guerre in June 1945. See Marie-Thérèse Chabord, 'Le Comité d'histoire de la Deuxième guerre mondiale et ses archives', La Gazette des archives, 116 (1982), 5-19; http://www.persee.fr/doc/gazar_0016 5522_1982_num_116_1_2790 (last visited 18 Sept. 2018).

14 Alya Aglan, Mémoires résistantes: histoire du réseau Jade-Fitzroy, 1940-1944 (Paris: Éditions du Cerf, 1994) and La résistance sacrifiée: le mouvement Libération-Nord (Paris: Flammarion, 1999); Olivier Wieviorka, Une certaine idée de la Résistance: Défense de la France: 1940-1949 (Paris: Le Seuil, 1995); Laurent Douzou, La Désobéissance: histoire d'un mouvement et d'un journal clandestins, Libération-Sud, 1940-1944 (Paris: Odile Jacob, 1995).

15 L'Ordre de la Libération was created by General de Gaulle in November 1940: 1,036 women and men were granted the Croix de la Libération before January 1946. Winston Churchill (1958) and King George VI (1960) were latterly made members of this prestigious Order. 
was that historians of the resistance tended to be former resisters. For many it was a crucial period in their lives: little wonder, therefore, that they should scrutinise everything published on the subject and react so strongly whenever they disagreed. This superposition - one might even say confusion - of actors and historians lasted a considerable length of time. Indeed, former resisters have continued to play a key role, with Jean-Louis Crémieux-Brilhac being by far the best historian of Free France ${ }^{16}$ and Daniel Cordier a major contributor to the knowledge of the resistance as viewed from the top (la Résistance des chefs) through his books on Jean Moulin, his boss for a year during the resistance itself. ${ }^{17}$

For political and ideological reasons communists tried hard to make their presence felt in this historiographical field. Because of the Cold War they wanted their part in the resistance to be acknowledged and even magnified. Obsessed with the hazy period between 1939 and 1941 when the party apparatus linked to Moscow was not committed to outright resistance, they endeavoured - though failed - to control the history that was written. ${ }^{18}$ In practice Gaullist memory gradually triumphed over its communist counterpart. ${ }^{19}$

Yet even beyond this consideration the historiography of the resistance has retained a very particular and even precious status, linked to the assumption that it must be written only with the utmost care and respect. To be sure, many of the books appearing on the subject from the 1950s to the end of the 1970s were serious and reliable works of scholarship. ${ }^{20}$ Yet it is striking to notice that they remained on the methodological sidelines of the new approaches then dominant in the writing of History, not least with the success of the Annales school. In contrast, resistance historiography remained strongly positivist in approach.

An important change occurred at the very beginning of the 1980s, when a new laboratory was founded to replace the CH2GM that had controlled the field since the 1950s: The Institute of Contemporary History (Institut d'Histoire du Temps Présent; IHTP). As the founder and director of this new laboratory, François Bédarida chose to insist on a theoretical reflection about the history of the present time. In particular, he emphasised that writing a history still in living memory could not be done without meditating on the difficulties that every historian would inevitably encounter on such a path. ${ }^{21}$ Here he worked closely with one of the leading specialists on the French resistance, Jean-Pierre Azéma. ${ }^{22}$ In parallel, a new generation of scholars was also taking to this historiographical field, which initiated a further substantial shift. Most of these scholars found a kind of logistical and intellectual shelter at the IHTP, which was an extremely welcoming, attractive and efficient research centre. This generation - the term is used here not to imply proximity in age but rather to denote a shared set of questions and approaches - worked on subjects such as public opinion, including representations and what is described as

16 Jean-Louis Crémieux-Brilhac (1917-2015) wrote the impressive La France Libre. De l'appel du 18 juin à la Libération (Paris: Gallimard, 1996) and De Gaulle, la République et la France libre: 1940-1945 (Paris: Perrin, collection 'Tempus', 2014).

17 Born in 1920, Daniel Cordier was the closest collaborator of Jean Moulin in 1942-3.

18 Typical of this behaviour is Le Parti communiste français dans la Résistance (Paris: Éditions sociales, 1967), written by Germaine Willard, Jean Gacon, Basile Sarivas and Henri Rol-Tanguy.

19 Pierre Nora, 'Gaullistes et communistes', in Pierre Nora, ed., Les Lieux de mémoire (Paris: Gallimard, collection Quarto), vol. 2, 2489-2532.

20 See, for example, the seventeen titles published in the collection 'Esprit de la Résistance' by the Presses Universitaires de France between 1954 and 1968 under the supervision of Henri Michel, director of the Comité d'Histoire de la deuxième Guerre mondiale.

21 See, for example, Écrire l'histoire du temps présent. En hommage à François Bédarida. Actes de la journée d'études de l'IHTP, 14 mai 1992 (Paris: CNRS Éditions, 1993) and François Bédarida, 'La dialectique passé/présent et la pratique historienne', in François Bédarida, ed., L'Histoire et le métier d'historien en France, 1945-1995 (Paris: Éditions de la Maison des sciences de l'homme, 1995).

22 Jean-Pierre Azéma was the author of a knowledgeable synthesis, De Munich à la Libération, 1938-1944 (Paris: Le Seuil, 1979). 
'the imaginary' ('l'imaginaire', Pierre Laborie), ${ }^{23}$ the sociology of the resistance (Jacqueline Sainclivier), ${ }^{24}$ underground publications (François Marcot) ${ }^{25}$ foreigners in the French resistance and the role of the Parisian police (Denis Peschanski), ${ }^{26}$ resistance and daily life (Dominique Veillon), ${ }^{27}$ resistance seen from below (Jean-Marie Guillon), ${ }^{28}$ anthropological approaches to the French resistance (Rod Kedward) ${ }^{29}$ and resistance in a specific locality (e.g. John Sweets, who focused closely on Clermont-Ferrand). ${ }^{30}$ During the 1990s these historians organised a series of six conferences that deeply revisited the history of the French resistance. ${ }^{31}$ These focused on three aspects: first, an attempt to give some elements of definition to what we call the resistance; second, the resistance as seen from below, a kind of 'résistance au village'; ${ }^{32}$ and third, a comparison with other resistances in European countries. What gradually emerged was a history that was both more conceptual and more complex.

At the same time these specialists in the history of the French resistance in France also became increasingly independent from the IHTP. Though the writing of this history continued to advance, it also fragmented - perhaps unsurprisingly, given the evolution of the discipline as a whole. The results of this movement of renewal culminated in 2006 with the Dictionnaire de la Résistance. $^{33}$

I would like at this point to emphasise some of the most promising new directions taken in recent years. These original approaches have often been the hallmark of young scholars supervised by a number of top-rank academic historians. The time when the whole field of resistance historiography was encompassed by a single institution - whether the CH2GM under the direction of Henri Michel between 1951 and 1980, or more recently the IHTP - has clearly passed, and research is now more closely dependent on the personal interests and curiosity of the individual scholar. In this sense the 'third generation' of resistance scholars seems to be more

${ }^{23}$ Pierre Laborie, Résistants, vichyssois et autres: l'évolution de l'opinion et des comportements dans le Lot de 1939 à 1944 (Paris: Éditions du CNRS, 1980); L’Opinion française sous Vichy (Paris: Le Seuil, 1990); Les Français des années troubles: de la guerre d'Espagne à la Libération (Paris: Desclée de Brouwer, 2001).

24 Jacqueline Sainclivier, L'Ille-et-Vilaine dans la Guerre: 1939-1945 (Le Côteau: Horvath, 1986); La Résistance en Ille-etVilaine: 1940-1944 (Rennes: Presses universitaires de Rennes, 1993).

25 François Marcot (with Angèle Baud; preface by Henri Michel), La Résistance dans le Jura (Besançon: Cêtre, 1985); Les voix de la Résistance: tracts et journaux clandestins francs-comtois (Besançon: Cêtre, 1989).

${ }^{26}$ Stéphane Courtois, Denis Peschanski and Adam Rayski, Le Sang de l'étranger: les immigrés de la MOI dans la Résistance (Paris: Fayard, 1989).

27 Dominique Veillon, Le 'Franc-tireur': un journal clandestin, un mouvement de Résistance: 1940-1944 (Paris: Flammarion, 1977); Journal et lettres de prison: 1941-1942/Boris Vildé (with François Bédarida) (Paris: IHTP, 1988); La mode sous l'Occupation: débrouillardise et coquetterie dans la France en guerre, 1939-1945 (Paris: Payot, 1990).

28 He wrote an outstanding thesis on the Var department defended in 1989, which was never published but can be found online: http://www.var39-45.fr/theseJMG/ (last visited 18 Sept. 2018).

29 Harry Roderick Kedward, Resistance in Vichy France: A Study of Ideas and Motivation in the Southern Zone, 1940-1942 (Oxford: Oxford University Press, 1978), translated into French as Naissance de la Résistance dans la France de Vichy (Seyssel: Champ Vallon, 1989); In Search of the Maquis: Rural Resistance in Southern France, 1942-1944 (New York: Oxford University Press, 1993), translated into French as À la recherche du Maquis (Paris: Cerf, 1999).

30 John F. Sweets, The Politics of Resistance in France, 1940-1944: A History of the Mouvements unis de la Résistance (Dekalb: Northern Illinois University Press, 1976); Choices in Vichy France: the French Under Nazi Occupation (New York/Oxford: Oxford University Press, 1986), translated into French as Clermont-Ferrand à l'heure allemande (Paris: Plon 1996).

31 Jean-Marie Guillon and Pierre Laborie, eds., Mémoire et Histoire: la Résistance (Toulouse: Privat, 1995); Jacqueline Sainclivier and Christian Bougeard, eds., La Résistance et les Français: enjeux stratégiques et environnement social (Rennes: Presses Universitaires de Rennes, 1995); Robert Frank and José Gotovitch, eds., La Résistance et les Européens du Nord (Brussels: CEGES, 1994); François Marcot, ed., La Résistance et les Français: lutte armée et Maquis, Annales littéraires de l'Université de Franche-Comté (Paris: Les Belles Lettres, 1996); Laurent Douzou, Robert Frank, Denis Peschanski and Dominique Veillon, eds., La Résistance et les Français: villes, centres et logiques de décision (Paris, IHTP-CNRS, 1995); Jean-Marie Guillon and Robert Mencherini, eds., La Résistance et les Européens du Sud (Paris: L'Harmattan, 1999).

32 Jean-Marie Guillon, 'La Résistance au village', in Jacqueline Sainclivier and Christian Bougeard, La Résistance et les Français. Enjeux stratégiques et environnement social (Rennes: Presses Universitaires de Rennes, 1995), $233-43$.

33 François Marcot, ed., Dictionnaire historique de la Résistance (Paris: Robert Laffont, 2006). 
open minded and freer than their predecessors (including myself). Partly this can be traced to a decline in the deep-rooted centralisation for which France is so well known, partly to a dramatic change in the questions posed to the past by the present.

\section{New Directions}

I do not intend to be comprehensive. Instead, I wish to offer a few insights into the latest historiographical trends, moving from more obvious points towards recent evolutions that are not always so easy to see or grasp. It is striking, indeed, how far some of the lacunae that I noted in an historiographical essay published in $2005^{34}$ have since been studied - such as relations with the Allies, the part played by the Giraudists, ${ }^{35}$ the secret services (the Bureau Central de Renseignement et d'Action, which depended on de Gaulle's administration in London and Algiers), the actual role of women in the underground conflict and so on.

In the last twenty years significant archives have become available, such as those of the Central Bureau of Intelligence and Operations (Bureau Central de Renseignement et d'Action; BCRA) and of the Special Operations Executive. Previously, these archives had been either closed or subject to restricted access. The result of such restrictions had been the writing of a kind of authorised history (such as by M.R.D. Foot, ${ }^{36}$ Colonel Passy, ${ }^{37}$ Charles de Gaulle ${ }^{38}$ and to some extent Daniel Cordier, who wrote mainly from the archives he kept at home). ${ }^{39}$ Other scholars had to rely on a small selection of published archival extracts, while the archives themselves were carefully preserved from prying eyes.

Changes in accessibility have, however, enabled important shifts in interpretation. In the case of the BCRA Sebastien Albertelli took advantage of the fact that its archives had opened to describe precisely how the service had been organised. ${ }^{40} \mathrm{He}$ showed in particular its political dimension, which was an essential aspect of its activity. Albertelli was harshly criticised during his $\mathrm{PhD}$ viva by actors who had been in close and permanent contact with the BCRA, not least Jean-Louis Crémieux-Brilhac, Daniel Cordier and Stéphane Hessel. Their criticisms reveal some of the constant tensions between memory and history - even though men like Crémieux-Brilhac and Cordier had themselves written academically rigorous historical studies. Albertelli's thesis was equally significant on another level. It proved that there were no complete and exhaustive archives of the BCRA, suggesting in turn that written archives are not - and never will be sufficient to grasp the reality of the past, even when this past is very recent. We should remain aware of the fact that secret services, wherever and whenever they act, do not care to give all the details of their actions: this would reveal too much of who they are, and of how they might react in a given context. As if by accident, files are often lost, irretrievably damaged by fire or water, etc. Every researcher works on partial archives, which should remind us of the danger of

34 Laurent Douzou, La Résistance française, une histoire périlleuse: essai d'historiographie (Paris: Le Seuil, 2005).

35 Named after General Henri Giraud, in December 1942 Darlan's successor in Algiers with Allied support, the Giraudists controlled the Organisation de Résistance de l'Armée (ORA), a branch of the French African Army in mainland France, and intelligence networks stemming from Vichy secret services.

36 M.R.D. Foot, SOE in France: An Account of the Work of the British Special Operations Executive in France, 1940-1944 (Government Official History), Whitehall History Publishing (First edition, London: Her Majesty's Stationery Office, HMSO, 1966). The book took four years to get clearance. He established his reputation with this publication, which was not translated into French until 2008; on the French side, some resistance groups regarded it as a criticism of their heroic myth.

37 Published in three volumes in 1947, 1948 and 1951, his memoirs were inaccessible until the publication of a new edition: Colonel Passy, Mémoires du chef des Services secrets de la France libre (preface and notes by Jean-Louis Crémieux-Brilhac) (Paris: Odile Jacob, 2000).

38 Charles de Gaulle, Mémoires de guerre. 1. L'Appel. 2. L'Unité. 3. Le Salut (Paris: Plon, 1954, 1956, 1959).

39 See, for example, Daniel Cordier, Jean Moulin: la république des catacombes (Paris: Gallimard, 1999).

40 Sébastien Albertelli, Les services secrets du général de Gaulle. Le BCRA, 1940-1944 (Paris: Perrin, 2009). 
developing any kind of cult of the written archives as revealing reality or so-called truth. This is one of the reasons why oral sources can so often be useful and enlightening.

In recent years resistance historiography has also encompassed new approaches to archives that were already more or less accessible. This is the case for all research concerning repression, the most extensively studied aspect of the period in the last ten years. Understanding the resistance requires a concomitant knowledge of its enemies, their methods and the extent of their powers. In this research area great advances have been made. Gaël Eismann, for instance, has studied the part played by the German Military Commanders in France (Militärbefehlshaber in Frankreich) located at the Majestic Hotel in Paris in the global strategy to maintain order and security in occupied France. ${ }^{41}$ In particular, she re-evaluated the degree of violence employed by the Wehrmacht in France, which dramatically increased as the war progressed. Gaël Eismann's book points out that the Wehrmacht was not the kind and 'correct' army so often described: ${ }^{42}$ instead, it was numerous and efficient, and similarly far removed from Robert Paxton's image of 40,000 men, mostly elderly and silver-haired, as given in Vichy France. ${ }^{43}$ With a similar perspective, other recent research has explored the repression of the resistance, with Cédric Neveu studying the Moselle, ${ }^{44}$ Laurent Thiery the Nord Pas-de-Calais, ${ }^{45}$ Thomas Fontaine the security services (Sicherheitspolizei und Sicherheintsdienst; SIPO-SD) in the occupied and non-occupied zones ${ }^{46}$ and Emmanuel Chevet examining the action led by the gendarmerie in France. ${ }^{47}$ These studies have made vital progress on three levels. First, they go beyond long-standing clichés to reveal the great variety of repressive forces (united by a lowest common denominator of anti-communism). Secondly, they often stress the significance of the ways in which the enemy was represented on both sides. Everyone fought in accordance with the image held of the enemy, and if this was true for the Wehrmacht and the SIPO-SD (or Gestapo), it was equally true for French police, Milice or gendarmerie. Third, these studies also reveal wide local variation across France, with repression particularly harsh in the forbidden zone, tough in the occupied zone and more moderate (at least until 1943) in Moselle, which the Nazis regarded as German territory. Moreover, these very different situations also diverged from what was happening in the non-occupied zone, and a supplementary distinction must be drawn between German behaviour and its Italian counterpart.

Although the French did not suffer as much as other occupied nations such as Poland or Yugoslavia, these studies prove that the French resistance had to learn gradually to cope with a great deal of violence, and a high level of brutality. When we think about repression, we need to draw not only on statistics (an important resource and one that has become more accurate in recent years), but we also need to consider the ways the repression worked, since this affected and shaped the modus operandi of the resistance. Studying repression in all these dimensions, we come closer to understanding that death was constantly on the mind of each resister, daily and insistently. Hence the intensity of underground life, which - both at the time but equally in the memory of its survivors - was unlike anything else. Something unheard of, 'almost a dream' (presque un songe), as Jean Cassou wrote in $1953 .^{48}$

41 Gaël Eismann, Hôtel Majestic - Ordre et sécurité en France occupée (1940-1944) (Paris: Tallandier, 2010).

42 This connects to larger historiographical discussions of the Wehrmacht in other contexts. See, for example, Omer Bartov, Hitler's Army: Soldiers, Nazis, and War in the Third Reich (Oxford: Oxford Paperbacks, 1992).

${ }^{43}$ On this controversy, see Robert Paxton and Peter Lieb, 'Maintenir l'ordre en France occupée. Combien de divisions?', Vingtième Siècle. Revue d'histoire, 112 (2011), 115-26.

44 Cédric Neveu, La Gestapo en Moselle: une police au cour de la répression nazie (Metz: Éditions Serpenoise, 2012).

45 Laurent Thiéry, La Répression allemande dans le Nord de la France, 1940-1944 (Villeneuve-d'Ascq: Presses universitaires du Septentrion, 2013).

46 Thomas Fontaine, 'Déporter. Politiques de déportation et répression en France occupée, 1940-1944', thesis defended on 28 March 2013, Université de Paris-1: https://tel.archives-ouvertes.fr/tel-01325232/document (last visited 18 Sept. 2018).

47 Emmanuel Chevet, 'Gendarmerie et maquis sous l'Occupation en France (1943-44): force est faiblesse', thesis defended on 25 February 2011 at the Université de Dijon.

48 Jean Cassou, La mémoire courte (Paris: Éditions de Minuit, 1953), republished by Mille et une nuits in 2001, 39. 
New approaches are linked, as we all know, to the interrogations that occupy our minds in the present time. We always interrogate the past from our position in the present, which in turn raises important questions. ${ }^{49}$

This is, for example, the case with gender studies. Although regularly celebrated, the part played by women in the resistance was not clearly established before the 1970s and 1980s, at the very moment at which the Women's Liberation movement was becoming both visible and influential. In the 1980s and 1990s Hanna Diamond, Paula Schwartz, Dominique Veillon and Danièle Voldman started working in this particular field. ${ }^{50}$ Since then the question of women's participation in the resistance has remained open but has often proved challenging to address as Claire Andrieu made only too clear in an important article for Le Mouvement Social. ${ }^{51}$ In a thesis devoted to the north of France, Catherine Lacour-Astol has helped to consider the question in new ways. ${ }^{52}$ She points out that although women's resistance was very efficient it can be difficult to uncover not only because it was often restricted to the domestic and private sphere of home, but also because it was determined by the ways in which authorities in charge of repression considered women. Nevertheless, research such as that of Catherine Lacour-Astol has shed light on this otherwise 'invisible' resistance.

Another novel topic has been treated by Johanna Barasz, ${ }^{53}$ who questioned the vichystoresistants, a concept formulated by historians in the 1990s to describe those who were simultaneously resisters and supporters of the Vichy regime. For many years the topic was taboo, given that the resistance was celebrated while Vichy was both hated and condemned. But gradually it became possible, and not necessarily irrelevant, to pose this question. Studying American, British, French and German archives, Johanna Barasz makes it very clear that some resisters, and not necessarily the most insignificant, both admired Pétain as a person and supported his policies. Yet - as she demonstrates - this situation of ambivalence could not persist beyond a certain limit. If these women and men (Marie-Madeleine Fourcade, General Gabriel Cochet, Henri Frenay, François Mitterrand, etc.) wanted to be part of the resistance, they had at some point to give up on Vichy. The decision they made was not immediate and not always as clear as we might wish to find it in retrospect. Barasz shows that there were what she calls 'métamorphoses'. Her approach is thought provoking in so far as it teaches us that what we might afterwards call the resistance was in fact a long and uncertain process during which people and situations changed dramatically. Her thesis underlines the importance of a feeling that Pierre Laborie studied for a long time: 'ambivalence'. ${ }^{54}$ Ambivalence is not synonymous with ambiguity, nor with duplicity. Taken from Freud, ambivalence is the observation that one may at the very same moment experience two totally contradictory feelings: we must resist, and we must support Pétain and the National Revolution. Ambivalence is not a permanent feeling but it does and did exist, and Barasz convincingly traces how it evolved month by month. Last but not least she reveals that Allies were often reluctant to take internal resistance seriously (since France had been

49 See Julien Blanc and Cécile Vast, eds., Chercheurs en Résistance. Pistes et outils à l'usage des historiens (Rennes: Presses Universitaires de Rennes, 2014).

50 See, for example, Paula Schwartz, 'Partisanes and Gender Politics in Vichy France', French Historical Studies 16, 1 (1989), 126-51, and 'Redefining Resistance: Women's Activism in Wartime France', in Behind the Lines: Gender and the Two World Wars, 1987, 141-53; François Rouquet and Danièle Voldman, eds., 'Identités féminines et violences politiques (1936-1946)', Les Cahiers de l'IHTP, 31 (Oct. 1995); Hanna Diamond, Women and the Second World War in France, 1939-1948: Choices and Constraints (London: Longman, 1999); Dominique Veillon, 'Les femmes dans la guerre: anonymes et résistantes', 1939-1945' in Combats de femmes (Paris: Autrement, 2001), 64-81.

51 Claire Andrieu, 'Les résistantes, perspectives de recherche', Le Mouvement social, 180 (1997), 69-96.

52 Catherine Lacour-Astol, Le Genre de la Résistance. La Résistance féminine dans le nord de la France (Paris: Presses de Sciences-Po, 2015).

53 Johanna Barasz, 'De Vichy à la Résistance: les vichysto-résistants 1940-1944', thesis defended on 11 February 2010 at Sciences Po, Paris.

54 Pierre Laborie's clearest explanation of this concept may be found in '1940-1944: Double-Think in France' in Sarah Fishman et al., eds., France at War, 181-90. 
overwhelmed, beaten, humiliated and was no longer a participant in the war) and experienced still greater difficulty in understanding what was actually happening in France. While the British had a fairly accurate measure of the situation early on in the war, the Americans persistently failed to achieve this - which explains their extended support for vichysto-resistants, even when the influence of this group had become virtually non-existent.

A further new direction to emerge in recent years could be qualified as conceptual, anthropological and empirical. This approach attributes great importance to the experience of resisters. It is not entirely novel: Rod Kedward initiated this type of study in the 1970s. What is new is that the approach now appears to be what economists would call a trend. Conceptual approaches can, for instance, be illustrated by Cécile Vast's thesis on the nature of the resistance. ${ }^{55}$ Based on sophisticated lexicological methods, her study, which focuses mainly on the resistance in the southern zone of France, insists on the deep changes that the identity of the resistance underwent between 1940 and 1944. She reveals in particular that the notion and feeling of identity did not have anywhere near the same meaning at different levels in the resistance. Her study shatters some stereotypes, especially that of an atemporal identity continuing unchanged through the dark years. Such research is characteristic of new approaches in its degree of emphasis on close textual analysis (and indeed several clandestine texts have been published in recent years with helpful critical apparatuses).

Very different is the approach adopted by two theses defended in 2008 by Sylvain Gregori (on the resistance in Corsica ${ }^{56}$ and Julien Blanc (on the réseau du Musée de l'Homme). Both of these studies are clearly anthropological. Sylvain Gregori's thesis (still unpublished) goes beyond the facts and chronology in order to understand how the resistance could find its way forward in a very peculiar society, marked by close ties and close adversities between people and families who knew each other intimately. He also deals with a complex issue: how did the Corsican people, who had been Italian for centuries, deal with Italian occupation? Julien Blanc worked on a very different field, focusing on the beginnings of the resistance in the occupied zone. ${ }^{57}$ Twenty or thirty years ago Julien Blanc would probably have taken the well organised archives of Germaine Tillion as a treasure, and as somehow unquestionable. He would have written a classical history of a resistance movement, something like the book published by Martin Blumenson on the Musée de l'Homme network. ${ }^{58}$ Yet his approach was strikingly different. First, he met Germaine Tillion regularly for years and listened carefully to what she told him: she was a prominent ethnologist, and she had always thought about classifications such as those she had formulated in the 1930s when studying the populations in the Algerian Massif of Aurès. She was then on the ground, living with the Chouai people, three days away by horse from the nearest small town. Second, Julien Blanc remained on the alert: he started exploring the archives and his perception evolved gradually. His hypotheses changed, and his thesis took him almost ten years to complete, whereas he was expected to finish in five. Some historians - among them Rod Kedward - found his thesis extremely empirical, which was true. But that is what makes his study so special and thought provoking. Julien Blanc has a solid academic trajectory, yet he did his best to forget this entirely and to immerse himself in and discover the world he wanted to explore. This behaviour breaks with what Pierre Bourdieu described as the habitus, ${ }^{59}$ behaviour so deeply rooted that we do not even notice it, and indeed even often ignore the fact that we are doing exactly what is expected from us. Instead of a well organised garden, with neat lines and a carefully mown lawn, Julien Blanc reveals what he calls 'a nebula' (une nébuleuse). In order to understand this nebula

55 Cécile Vast, L'Identité de la Résistance. Être résistant, de l'Occupation à l'après-guerre (Paris: Payot, 2010).

56 Sylvain Gregori, 'Entre continuité et rupture: résistance(s) et société Corse (juillet 1940- septembre 1943)', thesis defended on 29 November 2008 at the Université d'Aix.

57 Julien Blanc, Au Commencement de la Résistance. Du côté du musée de l'Homme, 1940-1941 (Paris: Le Seuil, 2010).

58 Martin Blumenson, The Vilde Affair: Beginnings of the French Resistance (Boston: Houghton Mifflin, 1977).

59 See Pierre Bourdieu, Esquisse d’une théorie de la pratique (Genève: Éditions Droz, 1972) and Le Sens pratique (Paris: Éditions de Minuit, 1980). 
he studies the currents of opinion in northern France in 1940-1. And what he describes does not look like anything we have ever read.

Blanc's study can be situated in a wider domain of interest to many current researchers: the relationship between the resistance and its social background. He demonstrates that far beyond the so-called 'réseau du Musée de l'Homme', a wide network was built very quickly, as quickly as it then disappeared in the wake of its repression. But his originality is to reveal the extent to which even repression could not expunge all the actors of that previous nebula: some of those who escaped the German repression continued to act in other groups with other responsibilities, and they were then stronger because they had experienced the lack of professionalism in their former organisation. Therefore, it is no longer the French resistance as an entity that is being studied but rather French resisters more broadly, and not necessarily the most well known or famous among them.

Julien Blanc also insists on an aspect that has been ignored or underestimated: the lacunae in our documentation and the silences of these resisters - not only, of course, of those who died in the combat (like Boris Vidé and Anatole Levitsky, leaders of one branch of the network) but also of those who survived and remained silent until their deaths. Silence is indeed part of this story and must be taken into account. Many pieces of the puzzle are lacking. And the puzzle, as it is later pieced together, is a construction that owes much to the reconstructions of memory and to the pressures of the post-war administration, which needed clear answers to the question of who deserved what. There is a gap between the reality known and lived by the resisters and what appears when the reconstruction is complete. Nobody can fill this void, which is consubstantial with the reality being studied. But historians can and must try to do so. As Albert Camus wrote, 'one must imagine Sisyphus happy'. 60

There is a wonderful study to be written on the silence and the silences of resisters. ${ }^{61}$ Indeed, this became obvious to me when I met Jean-Pierre Vernant, a resister and an anthropologist of Ancient Greece. We met initially because he had been an important member of Libération-Sud. He received me in his office at the Collège de France, where he was a professor, and I continued to meet up with him many times in the years that followed. Though always very kind and eager to help, he was never very talkative about his own experiences. He tended to reason in general and very interesting terms, but he would not speak about his personal feelings. I read his articles and books, and I realised that he had never written about the resistance. Yet I could see that his personal experience was below the surface of some of his writings. He published, for example, an article about 'the beautiful death' (La belle mort) in Ancient Greece, dealing ostensibly with Homer and with Greek mythology. ${ }^{62}$ Yet to a scholar who was studying the resistance this piece also appeared as a reflection on the death of his friends. At a seminar we held at the École des Hautes Études en Sciences Sociales, Pierre Laborie and I asked Vernant to speak about his experiences as a resister. Then ninety years old, he agreed to examine the link between his academic research and his experience of the resistance. This link, it turned out, was powerful indeed. ${ }^{63}$ Moreover, the silence Vernant maintained until his 'coming out' was not exceptional: many resisters did not speak in this capacity and kept for themselves what belonged to a kind of

60 Published in France in 1942, Le mythe de Sisyphe was translated into English by Justin O' Brien in 1955 as The Myth of Sisyphus and Other Essays (New York: Knopf).

61 See, for example, Pierre Laborie's study 'Silences de la mémoire, mémoires du silence', in Les Français des années troubles and Laurent Douzou, 'Les silences d'un résistant', in Maurice Olender, François Vitrani, eds., Jean-Pierre Vernant. Dedans dehors (Paris: Le genre humain, Seuil, 2013), 21-7. See also on another historical period with some useful theoretical work, Theo Jung, 'Le Silence du peuple: the rhetoric of silence during the French Revolution', French History, 31 (Dec. 2017), 440-69.

${ }^{62}$ Jean-Pierre Vernant, 'La belle mort et le cadavre outragé': http://books.openedition.org/editionsmsh/7734?lang=fr (last visited 18 Sept. 2018).

63 Jean-Pierre Vernant, La Traversée des frontières. Entre mythe et politique II (Paris: Seuil, 2004), 17-59. 
intimacy. ${ }^{64}$ To understand these silences more fully one would also need to delve into the importance of family, the notion of solidarity and the implicit bonds woven when there is so much at stake.

This leads me to the very last contemporary approach I would like to emphasise: the field of resistance memory. Pierre Laborie wrote a leading book on the subject entitled The Sorrow and the Poison (Le chagrin et le venin): an implicit reference to Marcel Ophuls's famous film The Sorrow and the Pity (Le chagrin et la pitié), made in 1969 and released in $1971 .^{65}$ Ophuls's film revealed that France under the occupation had not been as brave as it would have wished to appear, proving his point with a series of small cowardly acts on the part of the French. He made it very clear that the so-called 'dark years' had in fact been presented through rose-tinted spectacles. In 1973 the translation into French of Vichy France by Robert Paxton went further and deeper by demonstrating that the Vichy Regime was fully accountable for the policies it implemented. Since then a darker view of French behaviour during the Second World War became what Pierre Laborie described in his book as a 'vulgate', and his aim was to scrutinise the genealogy of this view. According to Laborie, the reality was far more complex than the image so often presented today, with 100,000 resisters, 100,000 collaborators and nearly 40 million people living in stubborn and cautious 'politics of patience' (attentisme). Bringing together a conceptual framework with his own knowledge of the resistance, Laborie calls for a vision of the period that takes ambivalence into account. He asserts that French people experienced both 'double thinking' and 'double lives' on an everyday basis. He is convincing when he invites us to be aware of the fact that a minority is not necessarily marginal, not necessarily a dissident minority. His opponents argue that he rehabilitates an old-fashioned view of the resistance. It is a clever attack, but I am not sure it refutes his demonstration.

Laborie's book stresses the fact that the historiography of the resistance in France has always been an ideological battlefield. For me, the changes I have highlighted in this article were encapsulated in an experience of May 1997 when, on the initiative of the local edition of the newspaper Libération, a meeting was organised to address the accusation of treason levelled against Lucie and Raymond Aubrac, following a plea written by Klaus Barbie and his lawyer. The historians present (Jean-Pierre Azéma, François Bédarida, Daniel Cordier, Henry Rousso, Dominique Veillon and I) declared that Lucie and Raymond Aubrac were not traitors. But, at the same time, for the entire day, most of these historians kept asking the same questions and wondered why they could not receive proper answers. The symbolic killing that the meeting involved was not of course well received, either by the Aubracs or by Maurice Agulhon, JeanPierre Vernant and myself, who were also part of this dark day. Ultimately the Libération meeting proved an embarrassment for everybody, including the attending historians, who were criticised by many of their colleagues. Contrary to what is sometimes asserted, the intention of the meeting was less to clarify points that had remained unclear for decades than to signify that history, as a discipline, should get rid of the actors. Though some of the attending actors persist in thinking that only the method was culpable, ${ }^{66}$ it seems to me that it was a profound mistake. ${ }^{67}$ In crossing the line in such a violent manner, historians transgressed the boundaries of their role. Marc Bloch assigned to historians the task of understanding, not judging. ${ }^{68}$

64 Jean-Pierre Vernant, Entre mythe et politique (Paris: Seuil, 1996), 17-31.

65 Pierre Laborie, Le Chagrin et le venin. La France sous l'Occupation, mémoire et idées reçues (Paris: Bayard, 2011).

${ }^{66}$ Henry Rousso, 'From a Foreign Country', in Manuel Braganca, Fransiska Louwagie, ed., Ego-histories of France and the Second World War. Writing Vichy (Basingstoke: Palgrave Macmillan, 2018), 98-9.

67 See Laurent Douzou, 'Resisting Fragments', in Manuel Braganca and Fransiska Louwagie, ed., Ego-histories of France and the Second World War. Writing Vichy (Basingstoke: Palgrave Macmillan, 2018), 60. See also Donald Reid, Germaine Tillion, Lucie Aubrac, and the Politics of Memories of the French Resistance (Cambridge: Cambridge Scholars Publishing, 2007).

68 See March Bloch, Apologie pour l'Histoire ou Métier d'Historien (Paris: Librairie Armand Colin, 1949), chapter IV. Bloch wrote this book in 1941-2. Arrested in March 1944 as a resister, he was shot by the Germans in June 1944. 
In fact, this painful and pointless meeting at Libération reveals the extent to which the resistance remains a sensitive issue. Debates continue among historians working on the occupation. Some argue that a pious legend prevents us from scrutinising the resistance without prejudice or fear. The truth is that the resistance does not require a myth of spotless heroism and purity. Indeed, ignoring its weaknesses and failings, as if it needed to be protected from proper historical scrutiny, lessens its achievement. ${ }^{69}$ Nonetheless, this statement must not lead us to ignore the strangeness and complexity of a very peculiar history that, in a landscape of mediocrity, took a path that is far from easy to grasp, or to understand.

Cite this article: Douzou, L. 2019. A Perilous History: A Historiographical Essay on the French Resistance. Contemporary European History 28: 96-106. doi: 10.1017/S0960777318000619

${ }^{69}$ Cited from Ruth Harris, The Man on Devil's Island. Alfred Dreyfus and the Affair that Divided France (Allen Lane, 2010), 384. 